\title{
Development and Use of Information and Digital Technologies at Ukrainian Enterprises
}

\author{
Marta Shkvaryliuk ${ }^{1}$, Liliana Horal $^{2}$, Inesa Khvostina ${ }^{2}$, Alla Maksymova ${ }^{3}$, and Vira Shyiko ${ }^{2}$ \\ ${ }^{1} \mathrm{NBU}$, Editorial Department, 01001 Kyiv, Ukraine \\ ${ }^{2}$ IFNTUNG, 76000 Ivano-Frankivsk, Ukraine \\ ${ }^{3}$ Kryvyi Rih Vocational College of State University of Economics and Technology, 50000 Kryvyi Rih, Ukraine
}

\begin{abstract}
The paper considers the problems consider the problems of enterprises digitalization. Based on the research of the scientific literature, it is established that enterprises in the modern world need the active introduction of information and digital technologies to ensure the competitiveness of production and active development in the future. The analysis and assessment of the use and development of communication and information technologies by domestic enterprises is carried out. According to its results, it is established that the main areas of information and communication technologies implementation in domestic enterprises are cloud computing services, sources of "big data" for the analysis of "big data", 3D printing, external links to the Internet, own websites and electronic trade via the Internet, etc. It is determined that due to the rather intensive growth of the number of enterprises in the information and communication industry, the use of their developments in production is rather insignificant. Only 5\% of enterprises during the study period used all the above information technologies in their activities. Based on the analysis, the problem areas of the process of implementation and development of communication and information technologies at domestic enterprises are identified and recommendations for improving the efficiency of information and communication technologies are provided. The MatLab Statistic Toolbox built into MatLab is used to determine the trends of the impact of digital innovations and the number of information and communication enterprises on GDP.
\end{abstract}

\section{Introduction}

The digital world evolves at a tremendous rate in the last decade. The development of the Internet, mobile communications and online services is a basic tool for shaping the digital economy. These processes affect all sectors of the economy and social activities, manufacturing, health care, education, finance, transport, and so on.

The increase in the efficiency of enterprises necessitates the optimization of the business process management system of the enterprise. This task cannot be solved today without the use of information systems and technologies, because the growth of information needs and the development of information services involves new priorities and requires the use of new management methods.

For Ukraine, it is absolutely necessary to move to an innovative model of enterprise development using the latest production technologies to realize the potential and effectively manage it. Ukrainian enterprises are undergoing significant transformations, in particular, they are taking place in the socioeconomic system in recent years and cause significant changes in the definition of development priorities. This is especially felt in the IT sector, which is constantly evolving, using the latest information technologies, introducing new technology for enterprise management. Most companies understand the need for innovation in the strategy, but few manage to implement this area and bring it to a logical conclusion, paying considerable attention to the internal business processes of the enterprise and their optimization. The growth of information volumes, information uncertainty, the complexity of information management of business processes of the enterprise determines the use of the latest information technologies. In addition, many companies in connection with the COVID-19 pandemic have switched to remote work and most likely this model of domestic enterprises will remain in the near future as there is evidence that real resources are saved if the enterprises are skillfully and intelligently managed according to a well-established system and wise use of innovative information and digital technologies. Therefore, there is a problem of analysis and evaluation of the use and development of information and digital technologies in domestic enterprises, development of recommendations for improving the functioning of enterprises in modern conditions and forecasting GDP depending on the introduction of innovations in domestic enterprises and changes in the number of information and communication enterprises.

\section{Literature review}

The problem of the development and use of information and digital technologies in the enterprises 
taking place in a society under the influence of digitization was considered by many authors: BerishaShaqiri Aferdita, Berisha-Namani Mihane [1], Thanos Papadopoulos, Konstantinos N. Baltas, Maria Elisavet Balta [2], Urbinati Andrea, Chiaroni Davide, Chiesa Vittorio and Frattini Federico [3], Melissa Liborio Zapata, Lamia Berrah, Laurent Tabourot [4], Robert Eller, Philip Alford, Andreas Kallmünzer, Mike Peters, Antecedents [5], Aijaz A. Shaikh, Ravishankar Sharma, Heikki Karjaluoto [6], Douglas Carl Engelbart, Joseph Carl Robnett Licklider, Richard Lipsey, Joseph Stiglitz [6], V. Soloviev, S. Semerikov, V. Solovieva [7], Horal Liliana, Korol Svitlana, Khvostina, Inesa, Shyiko Vira [8], Anders Olofsson, G. Fransson, J.O. Lindberg [9], V. S. Litvinenko [10], Ning Hu, Zhihong Tian, Hui Lu,Xiaojiang Du Mohsen Guizani [11], G. Mamonova, N. Maidaniuk [12], B. He, KJ. Bai [13], etc.

Berisha-Shaqiri, Aferdita \& Berisha-Namani, Mihane in the work [1] present the importance of information technology in economy, computerization trends and the opportunities offered by this technology where consumers have quick and easy access on the global market, as well as in information about goods and services [1]. Scholars [2] have highlighted the role of Digital Technologies (DT) in enhancing productivity and performance in Small and Medium Enterprises (SMEs). However, there is limited evidence on the use of DT for dealing with the consequences of extreme events, such as COVID-19. They discuss this gap by outlining potential research avenues and reflecting on the managerial implications of using DT within SMEs to deal with the repercussions of COVID-19 and securing business continuity. Urbinati, Andrea, Chiaroni, Davide, Chiesa, Vittorio \& Frattini, Federico [3] by adopting a capability-based perspective to identify the patterns of actions that firms have to deploy to use and implement a set of digital technologies in their innovation process, the paper [3] provides a map of enabled and enabling capabilities ensuing from and required for their use and implementation. From a methodological point of view, we conducted an exploratory multiple case study analysis, which involved a sample of eight companies operating in different industries and characterized by different size, market share and organizational structure [3]. The aim of paper [4] is to evaluates the facility of digital matureness models in their part of assisting producers of smart production in their digital conversion journeys and offer a set of recommendations to develop the usability of the toolbox in this scenario. To get off this, an evaluation of a extraction of seven matureness models is performed, using some design element to the special case of producers of smart production. In accordance with the most suitable findings, the propositions suggested for the formers are related to the ought for a wider area for the toolbox, a prescriptive state, and a wide business promising in the designation of their greatness. Confirmation of the suitability of the propositions in the small and medium business scenario is also capable through an demonstration of the producer of the Arve Valley [4]. Drawing on the resource-based view, Robert Eller, Philip Alford, Andreas Kallmünzer, Mike Peters, Antecedents first search the effect of three key SME powers on digitalization: digital strategy, employee skills, information technology. Second, they assess the effect digitalization has on financial efficiency. We then search if digitalization intermediates the effect of powers on efficiency. The results of a review of 193 SMEs show how digitalization can effect SME efficiency, with the three powers positively relating to digitalization. And severally, digitalization importantly relates to performance, mediating the impact of information technology on realization. Nevertheless does't mediate the impact of digital strategy or employee skills on efficiency [5]. Scholars [6] have noted that digital innovation is transforming the technological landscape, entrepreneurial practices, and the behaviours, attitudes, and beliefs of consumers across the globe. This research note serves three purposes. First, it introduces digital innovation and enterprise as a fruitful area of research in the sharing economy. Second, it extends the agenda set by Yoo, Henfridsson, and Lyytinen (2010) on "new organising logics of Digital Innovation" to propose contemporary research questions for scholarly collaboration. Third, it attempts to move forward research in digital business from $\mathrm{B} 2 \mathrm{~B}, \mathrm{~B} 2 \mathrm{C}$, mobile-social contexts to emerging eco-systems that address current socio-economic trends. In proposing such a digital business research agenda, the authors reason why Action Design Research studies may be particularly suited for the iterative development, replication and sharing of findings in the form of artefacts such as use-cases [6].

\section{Analysis and Methodology}

Examining the dynamics of the number of economic entities from 2011 to 2019 (table 1, figure 1) we can conclude that during this period the total number of economic entities increases from 1600127 units in 2012 to 1941701 units in 2019 , which indicates on the development of business activity in the economy. Calculating the number of enterprises by type of economic activity (table 1 ), we can determine that the largest share in the number of enterprises falls on those engaged in wholesale and retail trade; repair of motor vehicles and motorcycles and is 53\% in 2012 and 43\% in 2019. It should also be noted that in 2012 the next largest share of economic entities in the structure of the number of enterprises accounted for industrial enterprises and amounted to 7\%, while in 2019 the second largest share of enterprises was occupied by economic entities engaged in information and telecommunication activity - $11 \%$.

Figure 1 shows the dynamics of the number of enterprises by type of economic activity structure, excluding enterprises engaged in wholesale and retail trade; repair of motor vehicles and motorcycles. 
Table 1. Number of business entities by type of economic activity in 2012-2019 years, units.

\begin{tabular}{|c|c|c|c|c|c|c|c|c|}
\hline $\begin{array}{c}\text { The type of } \\
\text { economic activity }\end{array}$ & 2012 & 2013 & 2014 & 2015 & 2016 & 2017 & 2018 & 2019 \\
\hline $\begin{array}{c}\text { Agriculture, } \\
\text { forestry and fishing }\end{array}$ & 68497 & 71058 & 75660 & 79284 & 74620 & 76593 & 76328 & 75450 \\
\hline Industry & 114028 & 121244 & 131491 & 135149 & 127069 & 123876 & 125859 & 130324 \\
\hline Construction & 50830 & 52983 & 52189 & 55128 & 50208 & 50261 & 52531 & 56855 \\
\hline $\begin{array}{l}\text { Wholesale and } \\
\text { retail trade; repair } \\
\text { of motor vehicles } \\
\text { and motorcycles }\end{array}$ & 843075 & 890658 & 988694 & 989064 & 910413 & 837797 & 818217 & 834159 \\
\hline $\begin{array}{c}\text { Transportation and } \\
\text { storage }\end{array}$ & 87252 & 92366 & 111807 & 119037 & 109334 & 95815 & 90591 & 96235 \\
\hline $\begin{array}{c}\text { Accommodation } \\
\text { and food service } \\
\text { activities }\end{array}$ & 44085 & 52077 & 57553 & 58436 & 57696 & 57578 & 61761 & 69689 \\
\hline $\begin{array}{l}\text { Information and } \\
\text { communication }\end{array}$ & 66568 & 86377 & 114355 & 116136 & 129704 & 146909 & 174622 & 206147 \\
\hline $\begin{array}{c}\text { Financial and } \\
\text { insurance activities }\end{array}$ & 10342 & 11069 & 11888 & 12381 & 11865 & 10290 & 9739 & 10086 \\
\hline $\begin{array}{c}\text { Real estate } \\
\text { activities }\end{array}$ & 81726 & 92013 & 97794 & 94077 & 90921 & 90553 & 93383 & 98361 \\
\hline $\begin{array}{c}\text { Professional, } \\
\text { scientific and } \\
\text { technical activities }\end{array}$ & 87431 & 97052 & 115123 & 131035 & 125133 & 121546 & 126100 & 134800 \\
\hline $\begin{array}{l}\text { Administrative and } \\
\text { support service } \\
\text { activities }\end{array}$ & 38769 & 40191 & 44144 & 47361 & 45988 & 46553 & 49206 & 53787 \\
\hline Education & 7317 & 8467 & 10117 & 10873 & 11077 & 11656 & 13241 & 15429 \\
\hline $\begin{array}{c}\text { Human health and } \\
\text { social work } \\
\text { activities } \\
\end{array}$ & 16479 & 18048 & 21114 & 21683 & 21583 & 22085 & 24961 & 30994 \\
\hline $\begin{array}{l}\text { Arts, entertainment } \\
\text { and recreation }\end{array}$ & 9238 & 11620 & 13523 & 14887 & 13873 & 13045 & 13797 & 15168 \\
\hline $\begin{array}{l}\text { Other service } \\
\text { activities }\end{array}$ & 74490 & 76847 & 86709 & 89908 & 86147 & 100587 & 109336 & 114217 \\
\hline
\end{tabular}

Source: formed by the author on the basis of [15]

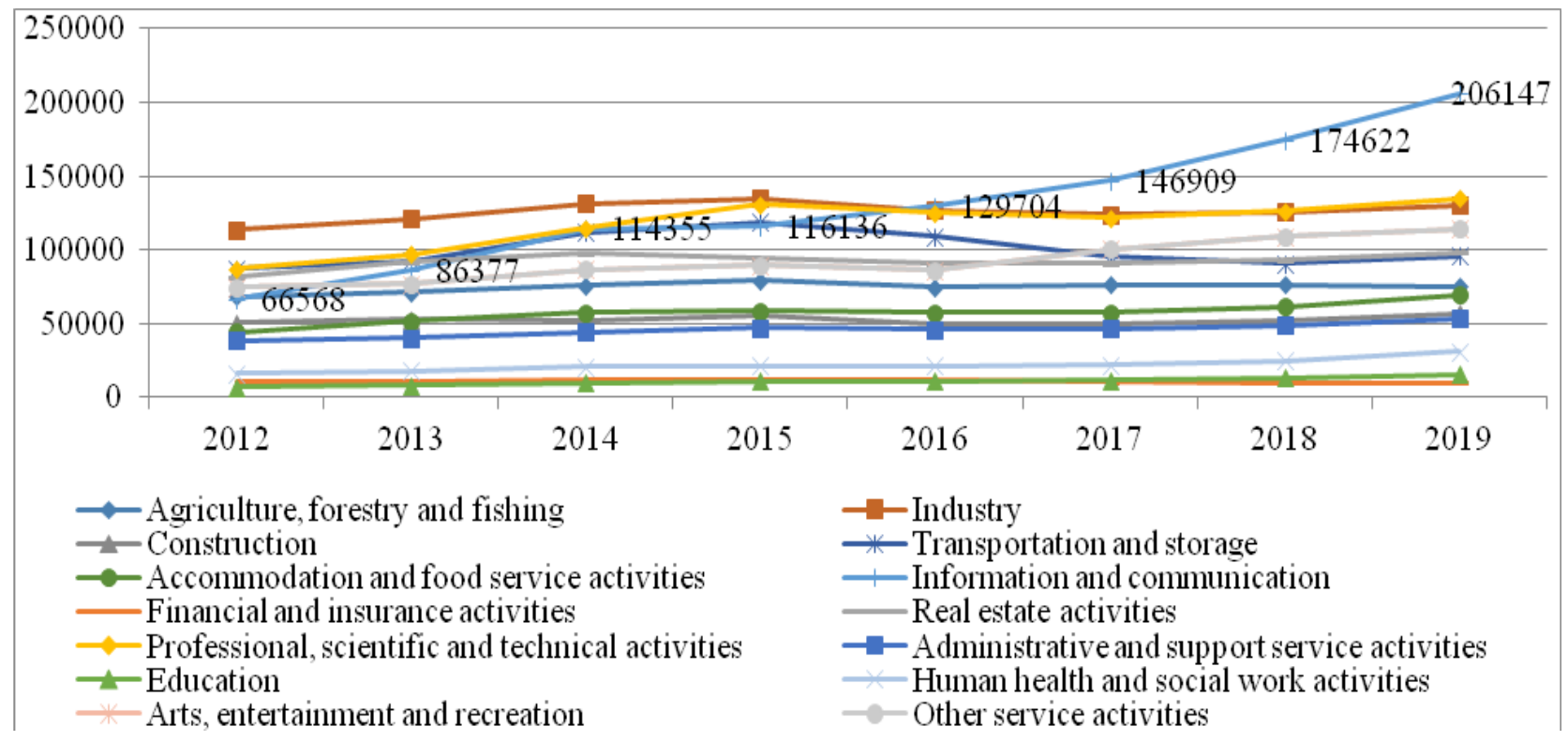

Fig. 1. Dynamics the number of business entities by type of economic activity in 2012-2019 years, units.

Source: built by the author

Thus, the growth of the share of enterprises engaged in information and telecommunications 
activities from 4\% in 2012 to $11 \%$ in 2019 indicates the formation of active demand for their services and favorable conditions for their operation (figure 2).

The results of calculating the dynamics of the number of business entities during the analyzed period showed that at the end of the period the number of enterprises engaged in information and telecommunications activities grew most intensively. There was an increase in their number by $210 \%$ compared to the base year 2012 (figure 3). The number of enterprises engaged in educational activities increased by $111 \%$ in 2019 compared to the base year 2012 and the number of enterprises in the field of health care and social assistance increased by $88 \%$. In general, we can note an increase in the number of enterprises in almost all activities, except wholesale and retail trade, repair of motor vehicles and motorcycles and financial and insurance activities, the number of which during the study period decreased by $1 \%$ and $2 \%$ respectively in 2019 compared to 2012 .

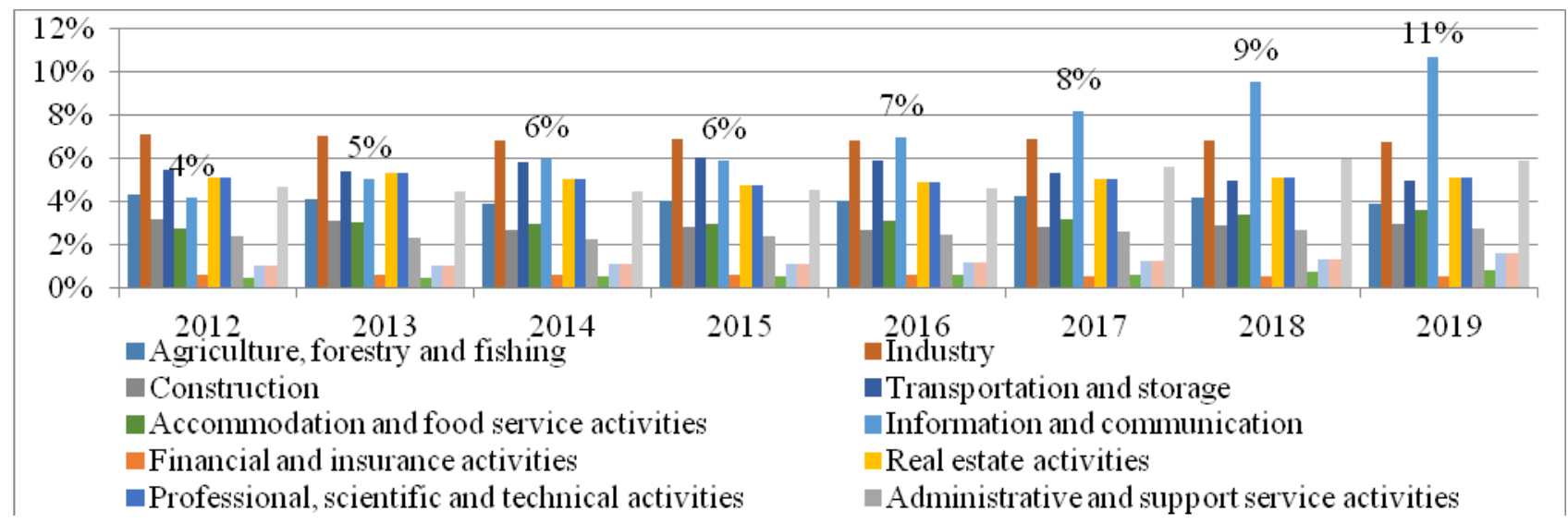

Fig. 2. Share of business entities by type of economic activity in total in 2012-2019 years, \%.

Source: built by the author

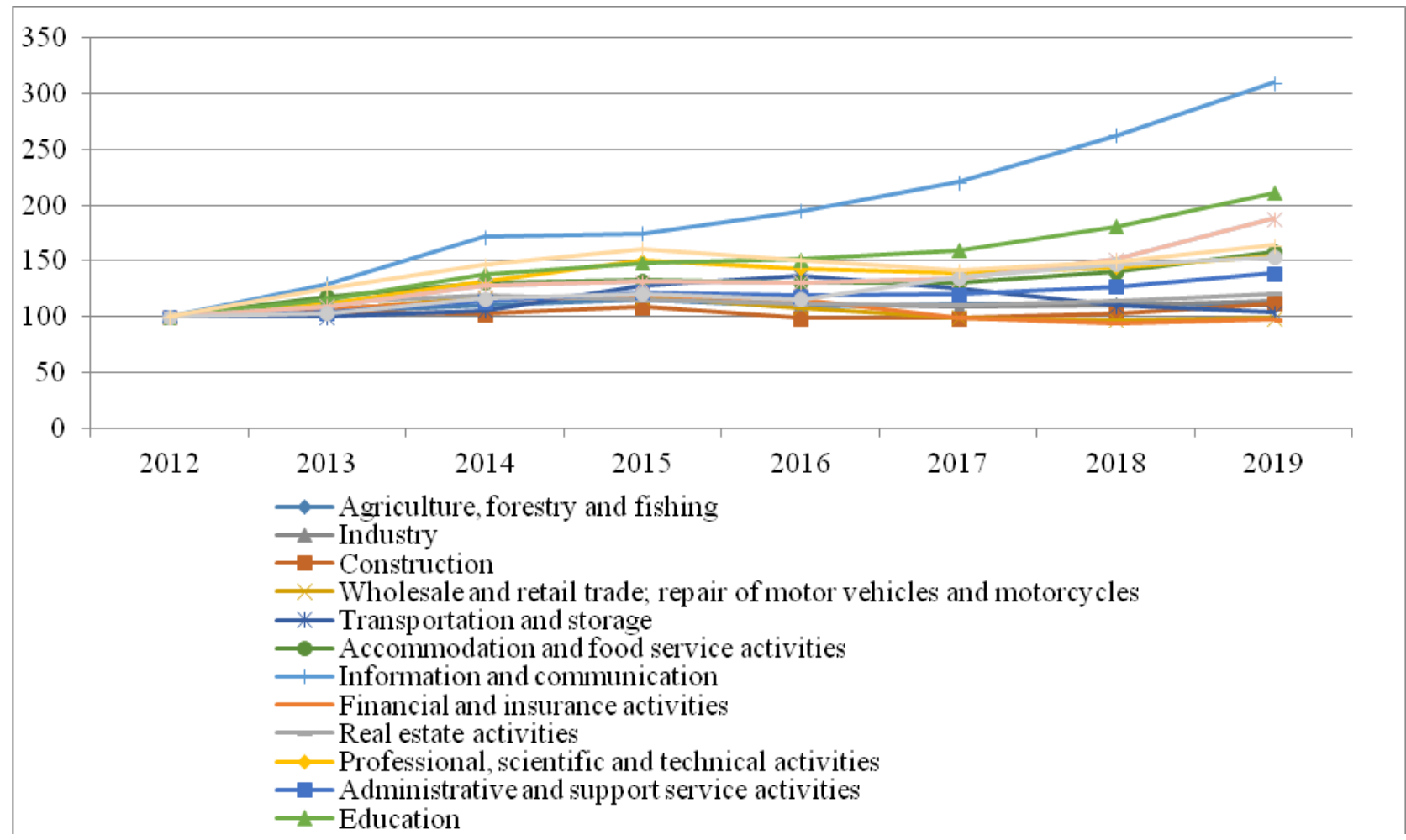

Fig. 3. Dynamics of number business entities by type of economic activity in total in 2012-2019 years, \%.

Source: calculated and built by the author

According to the information provided on the website of Ukrstat for the period from 2017 to 2019, statistical observations are conducted on the intensity of the information and communication technologies usage at domestic enterprises. Thus, according to the observations, domestic enterprises in their activities use cloud computing services, sources of "big data", 3$\mathrm{D}$ printing, information and communication 
technologies to provide invoices, carry out e-commerce via the Internet, actively establish external communication with the Internet and develop their own sites.

The use of these information and digital technologies and other types is a time requirement, which is declared in key documents: Industry 4.0 and domestic regulationsFor industrial enterprises, the transition to a digital economy has been defined as Industry 4.0 - the fourth industrial revolution. The use of the latest information technologies in business, economics, public administration and other fields is an extremely necessary condition for effective development. If this condition is not met at the appropriate level, there will be a slowdown in development and there will be an opportunity to get into the ranking of lagging behind and ineffective. The EU pays great attention to the development of the digital economy, believing that the level of the continent's economy will depend on how efficiently companies use digital technologies. Businesses that are not integrated into the digital space will not belong to the World Market.

Modern information technologies are computer processing of information according to pre-developed algorithms, storage of large amounts of information on various media, analysis and visualization of data and transmission of information at any distance in the shortest possible time. A new era has come - the era of "Big data" and "Data mining". 3D printers using viscous plastic instead of ink are becoming widespread. When working with a digital file, a 3D printer can "build" a three-dimensional object by printing out its "layers" in turn.

That is why in economics and business, information technology is used to process, sort and aggregate data, to organize the interaction of process participants and computers, to meet information needs, for operational communication at all stages and phases of the life cycle of the organization. In general, modern business to ensure a competitive position solves a threefold strategic task: first, it is necessary to establish closer relationships with suppliers and customers; secondly, to increase the level of own operational efficiency; third, to increase the competitiveness of products.

Table 2 shows the distribution of the number of enterprises by types of modern information and communication technologies used. Judging by the data given in Table 2, most domestic enterprises use external communication with the Internet in their activities. At the beginning of the study period, 39,528 companies were Internet users and their number increased to 43,758 units in 2019 . The growth rate of enterprises using the Internet is about $10 \%$ per year. It should be noted that the largest number of enterprises that have used this technology is in the processing industry, wholesale and retail trade; repair of motor vehicles and motorcycles and their number increases annually during the study period. In their activities, most companies use fixed broadband Internet access.

An important trend is the development and use of companies' own websites. In 2017, 16,240 companies had their own websites and their number grew every year, and in 2019 it was already 17,856 companies, which indicates a $10 \%$ increase in the number of companies that have their own websites.

Table 2. The use of different types of information technologies in domestic enterprises

\begin{tabular}{|c|c|c|c|c|c|}
\hline $\begin{array}{c}\text { The type of } \\
\text { information } \\
\text { technologies } \\
\text { used by } \\
\text { enterprises }\end{array}$ & $\mathbf{2 0 1 7}$ & $\mathbf{2 0 1 8}$ & $\mathbf{2 0 1 9}$ & $\mathbf{2 0 1 8 /}$ & $\mathbf{2 0 1 9 /}$ \\
\cline { 4 - 6 } $\begin{array}{c}\text { Cloud } \\
\text { computing } \\
\text { services }\end{array}$ & 4135 & 4831 & 5207 & 116,83 & 125,93 \\
\hline $\begin{array}{c}\text { Sources of } \\
\text { "big data" } \\
\text { for the } \\
\text { analysis of } \\
\text { "big data" }\end{array}$ & 10252 & 9188 & 9280 & 89,62 & 90,52 \\
\hline $3-D$ printing & & 1219 & 1471 & 100,00 & 120,67 \\
\hline $\begin{array}{c}\text { E-commerce } \\
\text { via the } \\
\text { Internet }\end{array}$ & 10764 & 12059 & 12609 & 112,03 & 117,14 \\
\hline $\begin{array}{c}\text { External } \\
\text { connection } \\
\text { to the } \\
\text { Internet }\end{array}$ & 39582 & 43303 & 43785 & 109,40 & 110,62 \\
\hline $\begin{array}{c}\text { Own } \\
\text { website }\end{array}$ & 16240 & 17522 & 17856 & 107,89 & 109,95 \\
\hline
\end{tabular}

Source: formed and calculated by the author on the basis of [15]

The next information and communication technology used by domestic enterprises is ecommerce via the Internet. And as can be seen from the table in 2017, this information and communication technology was used by 10,764 companies, there is an annual increase in the number of companies using this technology, namely in 2018 their number increased by $12.03 \%$ and amounted to 12059 units, and in In 2019, the growth rate was $117.14 \%$ of the base period, equal to 12,609 users. Over the past two years, there has been an increase in the volume of sold products (goods, services) received from trade through websites or applications from 228035634.7 thousand UAH in 2017 to 292731939.1 thousand UAH. in 2019, which is respectively $3.5 \%$ and $4.5 \%$ of the total sales of products (goods, services) of enterprises. It should also be noted that a larger number of domestic enterprises purchased goods or services via the Internet (except for orders sent by e-mail). Whereas the number of enterprises that received orders via the Internet for the sale of goods or services (excluding orders received by e-mail) was 2476 units in 2018 and 2440 units in 2019.

The trend of using "big data" sources for "big data" analysis is positive. Although at the end of the study period the number of enterprises that used this technology decreased compared to the base year 2017, but compared to the previous period their number increased from 9188 enterprises 2018 to 9280 enterprises in 2019. If we consider the distribution of the number of enterprises by sources of "big data" 
usage (Table 3), most companies analyze the "big data" using data obtained from smart devices or sensors. In 2017, the number of such enterprises was 3194 units, during the study period, their number decreased and in 2019 amounted to 2896 units, which is $10 \%$ less than the base period. During the study period encreases the number of enterprises that analyzed the "big data" based on geolocation data obtained from portable devices. At the beginning of the study period, their number was 1584 companies, and in 2019 their number increased by $18.31 \%$ and amounted to 1874 companies. Another source of "big data" is social media, which were used by 1,659 businesses at the beginning of the period, and at the end of the analyzed period their number decreased slightly and amounted to 1,600 companies in 2018 and 1,658 companies in 2019. To determine which companies are the most active "big data" users, a diagram was constructed with the distribution of the number of companies by industry. (Table 3).

As can be seen from Figure 4, the largest users of "big data" are enterprises in the processing industry $(23.02 \%)$, wholesale and repair of motor vehicles and motorcycles $(25.99 \%)$, construction $(9.32 \%)$, transport, warehousing, postal and courier delivery (9.20). In general, domestic enterprises analyze "big data" on their own $(71.5 \%)$.
Table 3. Number of enterprises that conducted "big data" analysis, according to "big data" sources

\begin{tabular}{|c|l|l|l|l|l|}
\hline \multirow{2}{*}{$\begin{array}{c}\text { "big data" } \\
\text { sources }\end{array}$} & $\mathbf{2 0 1 7}$ & $\mathbf{2 0 1 8}$ & $\mathbf{2 0 1 9}$ & $\begin{array}{c}\text { Grow/ } \\
\mathbf{2 0 1 7}\end{array}$ & $\begin{array}{c}\mathbf{2 0 1 9} \\
\mathbf{2 0 1 8}\end{array}$ \\
\hline $\begin{array}{c}\text { The data } \\
\text { obtained } \\
\text { from smart } \\
\text { devices or } \\
\text { sensors }\end{array}$ & 3194 & 2917 & 2896 & 91,33 & 90,67 \\
\hline $\begin{array}{c}\text { Geolocation } \\
\text { data obtained } \\
\text { from } \\
\text { portable } \\
\text { devices }\end{array}$ & 1584 & 1697 & 1874 & 107,13 & 118,31 \\
\hline $\begin{array}{c}\text { The data } \\
\text { generated } \\
\text { from social } \\
\text { media }\end{array}$ & 1659 & 1600 & 1658 & 96,44 & 99,94 \\
\hline $\begin{array}{c}\text { Other } \\
\text { sources }\end{array}$ & 3815 & 2974 & 2852 & 77,96 & 74,76 \\
\hline
\end{tabular}

Source: formed and calculated by the author on the basis of [15]

Cloud computing services were used by 4135 enterprises at the beginning of the analyzed period, it should be noted that in 2019 the number of such enterprises increased by a quarter and amounted to 5207 business entities.

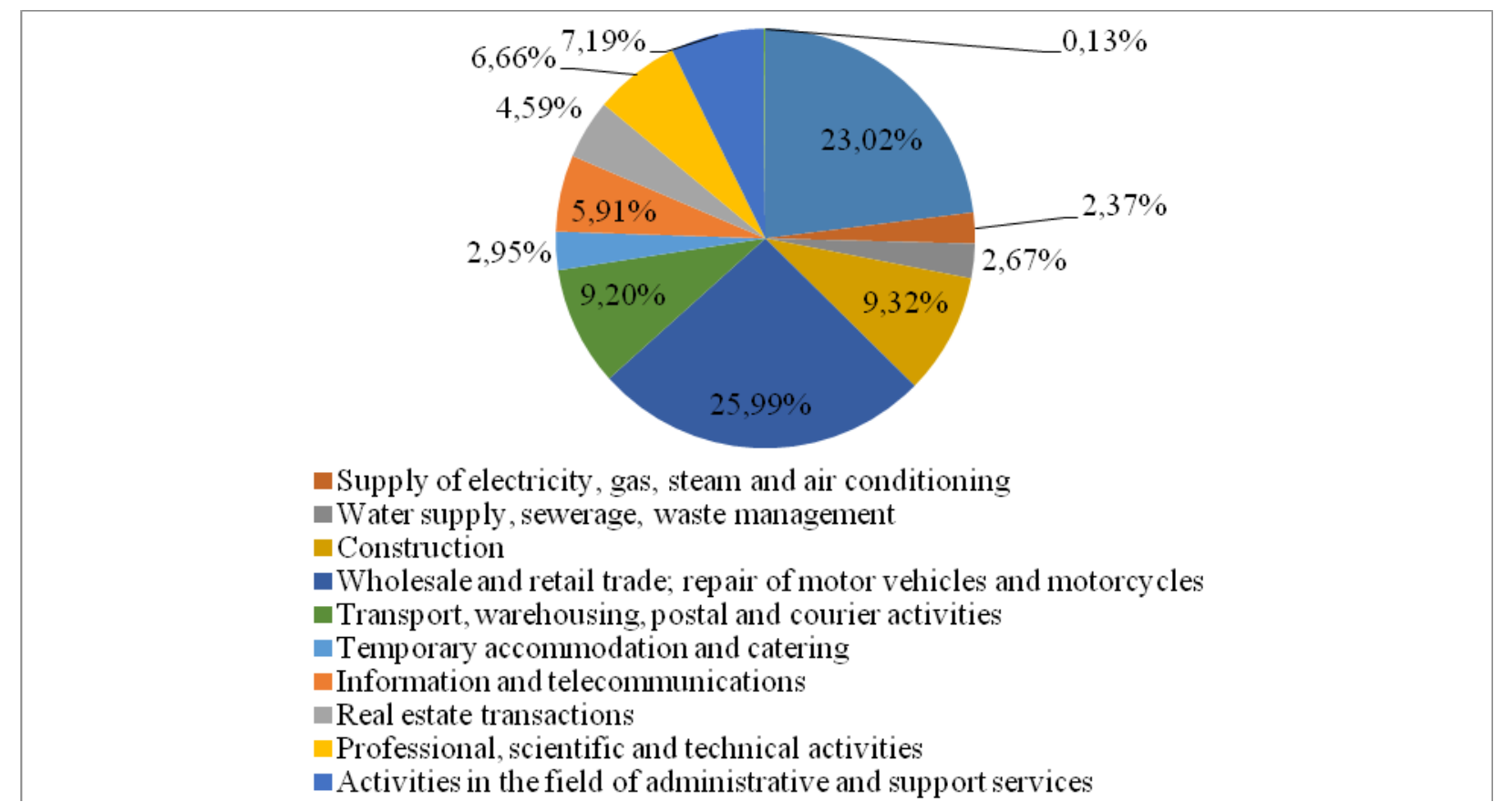

Fig. 4. Distribution of enterprises according to the level of "big data" usage in 2019

Source: built by the author

Examining the statistics of the types of cloud computing that enterprises use in their activities (Table 4 ), we can conclude that their number is growing every year. According to the information provided in Table 4, increases the number of enterprises purchasing file storage services from 1447 business entities in 2017 to 2139 in 2019 is growing the most, which is $47.82 \%$ more than in the base period. At the end of the period, the number of enterprises purchasing a database of enterprises increased by $40.92 \%$, if in 2017 the number 
of such enterprises was 1449, in 2019 there were already 2042 business entities.

The number of enterprises that use customer relationship management programs in their activities is growing from 1,050 businesses in 2017 to 1,453 in 2019 , which is $38.38 \%$ more than the base period. The number of enterprises purchasing e-mail services increased by $36 \%$ in 2019 and amounted to 2,972 business entities against 2,175 enterprises in 2017.

Table 4. Distribution of the number of enterprises that used cloud computing services in 2017-2019, units

\begin{tabular}{|c|c|c|c|c|c|}
\hline \multirow{2}{*}{$\begin{array}{l}\text { Types of } \\
\text { cloud } \\
\text { computing } \\
\text { services }\end{array}$} & \multirow[b]{2}{*}{2017} & \multirow[b]{2}{*}{2018} & \multirow[b]{2}{*}{2019} & \multicolumn{2}{|c|}{ Growth rate } \\
\hline & & & & $\begin{array}{l}2018 / \\
2017\end{array}$ & $\begin{array}{l}2019 / \\
2017\end{array}$ \\
\hline Email & 2175 & 2548 & 2972 & 117,2 & 136,6 \\
\hline $\begin{array}{l}\text { Office } \\
\text { software }\end{array}$ & 1932 & 2125 & 2445 & 110,0 & 126,6 \\
\hline $\begin{array}{l}\text { Enterprise } \\
\text { database } \\
\text { hosting }\end{array}$ & 1449 & 1664 & 2042 & 114,8 & 140,9 \\
\hline $\begin{array}{l}\text { File storage } \\
\text { service File } \\
\text { storage } \\
\text { service }\end{array}$ & 1447 & 1788 & 2139 & 123,6 & 147,8 \\
\hline $\begin{array}{l}\text { Financial or } \\
\text { accounting } \\
\text { applications }\end{array}$ & 2413 & 2585 & 3010 & 107,1 & 124,7 \\
\hline $\begin{array}{l}\text { Programs } \\
\text { for } \\
\text { customer } \\
\text { relationship } \\
\text { managemen } \\
t\end{array}$ & 1050 & 1223 & 1453 & 116,5 & 138,4 \\
\hline $\begin{array}{l}\text { Computer } \\
\text { power for } \\
\text { the } \\
\text { operation of } \\
\text { enterprise } \\
\text { software }\end{array}$ & 1341 & 1501 & 1761 & $\begin{array}{l}111,9 \\
3\end{array}$ & $\begin{array}{l}131,3 \\
2\end{array}$ \\
\hline
\end{tabular}

Source: formed and calculated by the author on the basis of [15]

On average, during the study period, $57 \%$ of enterprises in their activities purchased financial or accounting applications, 54\% - e-mail services, 46\% office software, $38 \%$ - file storage services, $36 \%$ - file storage hosting, $32 \%$ - computer power for the operation of enterprise software and 26\% - programs for relationship management.

Examining the statistics of the types of cloud computing that enterprises use in their activities (Table 4 ), we can conclude that their number is growing every year. According to the information provided in Table 4, increases the number of enterprises purchasing file storage services from 1447 business entities in 2017 to 2139 in 2019 is growing the most, which is $47.82 \%$ more than in the base period. At the end of the period, the number of enterprises purchasing a database of enterprises increased by $40.92 \%$, if in 2017 the number of such enterprises was 1449, in 2019 there were already 2042 business entities. The number of enterprises that use customer relationship management programs in their activities is growing from 1,050 businesses in 2017 to 1,453 in 2019 , which is $38.38 \%$ more than the base period. The number of enterprises purchasing e-mail services increased by $36 \%$ in 2019 and amounted to 2,972 business entities against 2,175 enterprises in 2017. Given the fact that domestic enterprises are actively using information and communication technologies, there is a growing need to increase computer capacity for the operation of enterprise software, so the statistics in Table 4 indicate that during the study period, the number of enterprises that increased computer capacity from 1341 enterprises in 2017 to 1761 in 2019 , which is $31.32 \%$ more than the base period. At the end of the period, the number of enterprises purchasing office software increased by $26.55 \%$ from 1,932 enterprises in 2017 to 2,445 in 2019. There is an annual growth of enterprises that use financial or accounting applications in their activities, namely, if in 2017 their number was 2413, then in 2019 their number increased by $24.74 \%$ and amounted to 3010 businesses. Figure 5 shows the shares of enterprises in the total number of enterprises (4135 in 2017, 4831 - in 2018, 5207 - in 2019) by types of cloud technologies used in their activities.

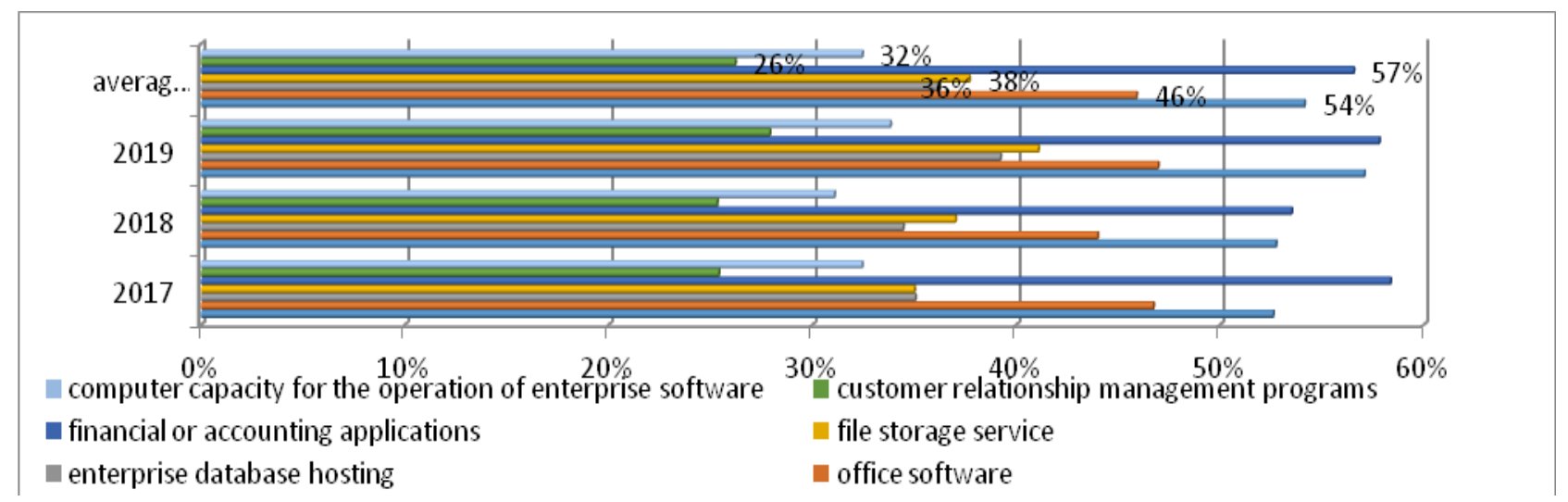

Fig. 5. Shares of enterprises in the total number of enterprises by types of cloud computing used in their activities. 
The most active users of cloud computing services during the analyzed period were wholesale and retail enterprises; repair of motor vehicles and motorcycles and the manufacturing industry account for an average of $28.10 \%$ and $23.16 \%$, respectively (Table 5). 9.88\% of construction companies use cloud computing in their activities. From $7 \%$ to $6 \%$ of enterprises in the field of professional, scientific and technical activities, information and telecommunications, administrative and support services, transport, warehousing, postal and courier activities use cloud computing services. In other industries, less than $5 \%$ of enterprises use cloud computing in their activities (Table 5).

An important component of the of domestic enterprises development in the context of active digitalization is the development and use of their own websites to improve their activities. According to the analysis, it can be concluded that at the beginning of the study period, 16,240 companies had their own websites, and in 2019 they became $9.95 \%$ more, ie 17,856 (Table 2.). The largest share of the enterprise on average for the studied period, which have developed websites, falls on the processing industry (30.14\%) wholesale and retail trade; repair of motor vehicles and motorcycles $(26.26 \%)$. In all other activities, less than $10 \%$ of businesses have their own websites.

Thus, according to the data in Table 6 , it can be concluded that the examined enterprises were mainly used for customer service $(47 \%$ of the surveyed enterprises). $46 \%$ of elaborated companies use sites to quickly find them on social media. In $30 \%$ of companies, websites advertise vacancies or apply for vacancies online. $29 \%$ of the websites of enterprises are formed in such a way that visitors have the opportunity to form orders for goods and services online and in $26 \%$ of cases the sites have the ability to monitor the status of placed orders.

$18 \%$ of the surveyed companies have the opportunity to supply products and services online on websites.

In less than $15 \%$ of companies, the developed websites have a personalized content of the website for regular or repeat customers and have the opportunity to train staff. Positive is the growing trend of all opportunities to use websites.

Table 5. Distribution of enterprises from their total number by types of economic activity that use cloud computing in their activities in 2017-2019

\begin{tabular}{|c|c|c|c|c|}
\hline $\begin{array}{c}\text { Type of economic } \\
\text { activity }\end{array}$ & 2017 & 2018 & 2019 & average \\
\hline Processing industry & $22,47 \%$ & $23,27 \%$ & $23,74 \%$ & $23,16 \%$ \\
\hline $\begin{array}{c}\text { Supply of } \\
\text { electricity, gas, } \\
\text { steam and air } \\
\text { conditioning }\end{array}$ & $1,86 \%$ & $1,51 \%$ & $1,71 \%$ & $1,69 \%$ \\
\hline $\begin{array}{l}\text { Water supply; } \\
\text { sewerage, waste } \\
\text { management }\end{array}$ & $2,08 \%$ & $1,76 \%$ & $2,07 \%$ & $1,97 \%$ \\
\hline Construction & $9,72 \%$ & $10,02 \%$ & $9,89 \%$ & $9,88 \%$ \\
\hline $\begin{array}{l}\text { Wholesale and } \\
\text { retail trade; repair } \\
\text { of motor vehicles } \\
\text { and motorcycles }\end{array}$ & $28,17 \%$ & $28,48 \%$ & $27,64 \%$ & $28,10 \%$ \\
\hline $\begin{array}{c}\text { Transport, } \\
\text { warehousing, postal } \\
\text { and courier } \\
\text { activities }\end{array}$ & $6,63 \%$ & $6,13 \%$ & $6,28 \%$ & $6,34 \%$ \\
\hline $\begin{array}{c}\text { Temporary } \\
\text { accommodation } \\
\text { and catering }\end{array}$ & $2,85 \%$ & $2,71 \%$ & $2,98 \%$ & $2,85 \%$ \\
\hline $\begin{array}{l}\text { Information and } \\
\text { telecommunications }\end{array}$ & $6,89 \%$ & $6,91 \%$ & $7,32 \%$ & $7,04 \%$ \\
\hline $\begin{array}{l}\text { Real estate } \\
\text { transactions }\end{array}$ & $4,43 \%$ & $4,33 \%$ & $3,99 \%$ & $4,25 \%$ \\
\hline $\begin{array}{c}\text { Professional, } \\
\text { scientific and } \\
\text { technical activities }\end{array}$ & $7,47 \%$ & $8,07 \%$ & $8,07 \%$ & $7,87 \%$ \\
\hline $\begin{array}{c}\text { Activities in the } \\
\text { field of } \\
\text { administrative and } \\
\text { support services }\end{array}$ & $7,23 \%$ & $6,54 \%$ & $6,16 \%$ & $6,65 \%$ \\
\hline $\begin{array}{c}\text { Repair of } \\
\text { computers and } \\
\text { communication } \\
\text { equipment }\end{array}$ & $0,19 \%$ & $0,27 \%$ & $0,15 \%$ & $0,21 \%$ \\
\hline
\end{tabular}

Source: formed and calculated by the author on the basis of [15]

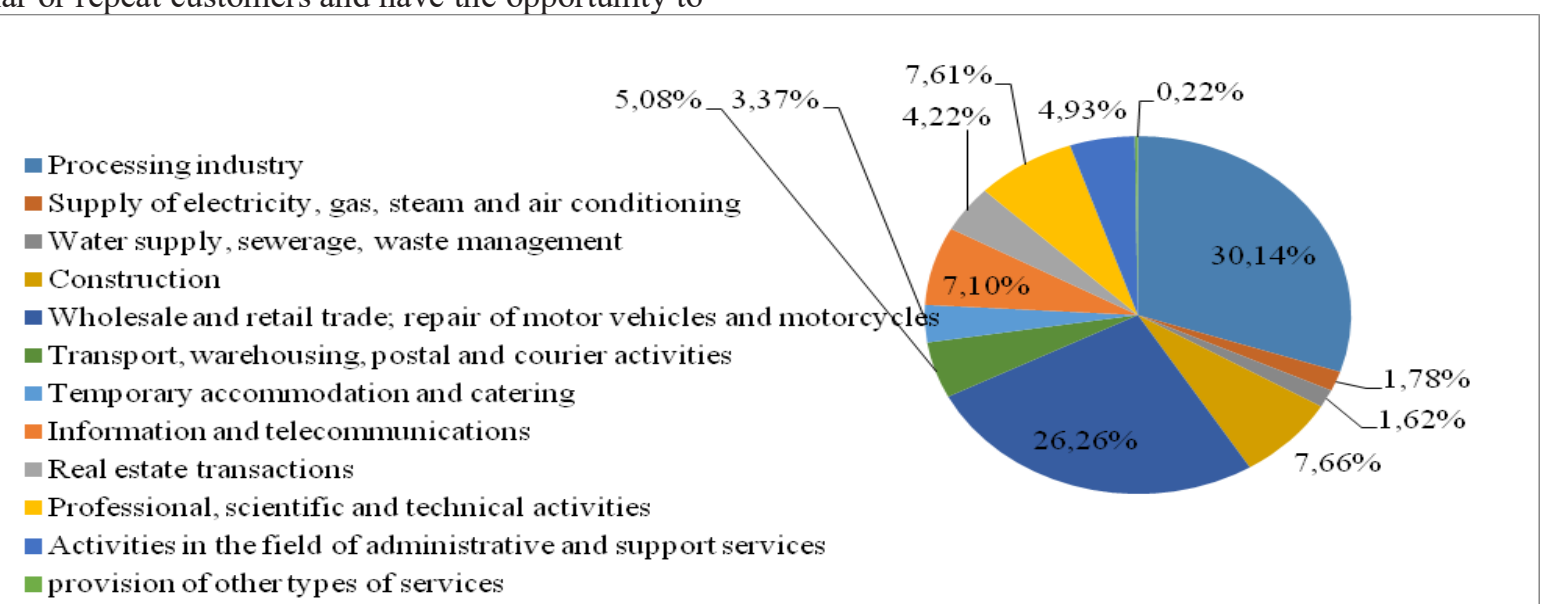

Fig. 6. Distribution of enterprises (on average for the study period) from their total number by type of economic activity, that have their own websites

Source: built by the author 
Table 6. Distribution of enterprises according to the capabilities provided by the developed website.

\begin{tabular}{|c|c|c|c|}
\hline $\begin{array}{c}\text { Possibilities of using } \\
\text { websites }\end{array}$ & 2017 & 2018 & 2019 \\
\hline customer service & $46 \%$ & $47 \%$ & $47 \%$ \\
\hline $\begin{array}{c}\text { delivery of products and } \\
\text { services online }\end{array}$ & $17 \%$ & $18 \%$ & $18 \%$ \\
\hline $\begin{array}{c}\text { the ability of visitors to } \\
\text { place orders for goods } \\
\text { and services online }\end{array}$ & $27 \%$ & $29 \%$ & $29 \%$ \\
\hline $\begin{array}{c}\text { monitoring the status of } \\
\text { placed orders }\end{array}$ & $25 \%$ & $26 \%$ & $26 \%$ \\
\hline $\begin{array}{c}\text { personalized content of } \\
\text { the website for regular or } \\
\text { repeat customers }\end{array}$ & $25 \%$ & $12 \%$ & $12 \%$ \\
\hline $\begin{array}{c}\text { links to the company's } \\
\text { website on social media }\end{array}$ & $42 \%$ & $46 \%$ & $46 \%$ \\
\hline $\begin{array}{c}\text { vacancy announcements } \\
\text { or applications for } \\
\text { vacancies online }\end{array}$ & $28 \%$ & $30 \%$ & $30 \%$ \\
\hline staff training & $10 \%$ & $11 \%$ & $11 \%$ \\
\hline
\end{tabular}

Source: formed and calculated by the author on the basis of [15]
Domestic enterprises actively use 3D printing technology in their activities. Official statistics on the number of enterprises since 2018. And as shown in table 2 in 2018, 1219 companies used 3-D printing in their activities, and in 2019 there were 1471. And it should be noted that $52 \%$ of the examined companies carried out 3-D printing with their own 3-D printers, and the remaining $48 \%$ of enterprises used $3 \mathrm{D}$ printing services provided by other enterprises. The uses of 3-D printer products are shown in Figure 6.

According to the results of statistical surveys (Figure 7 ) in $2019,48 \%$ of enterprises used printed prototypes and models for their own use, $37 \%$ of enterprises printed on 3-D printer products for use in the production process, $28 \%$ of enterprises used printed prototypes or models for sale and $19 \%$ of businesses used 3-D printers to print goods for sale, except for prototypes or models. About $40 \%$ of manufacturing enterprises use 3D printers in their activities, less often they are used by those enterprises that repair computers and communication equipment.

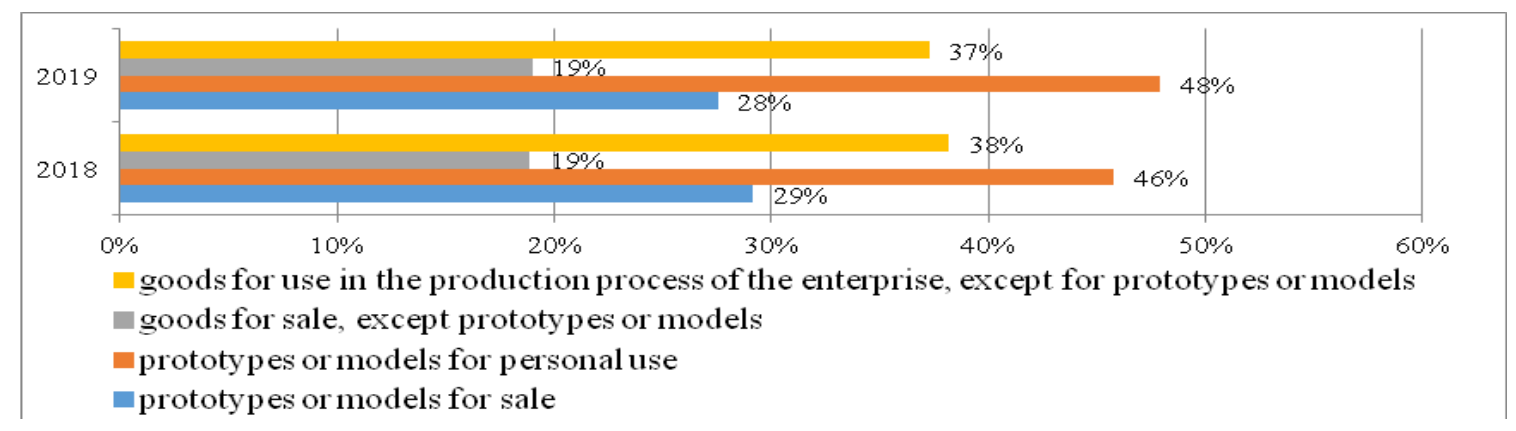

Fig. 7. Areas of products printed by 3-D printers usage

Source: built by the author

Having studied the processes of development and use of information and digital technologies at domestic enterprises, there is a need to determine the dependence of GDP on the number of enterprises that use information and digital technologies in their activities.

We will solve this problem in the MatLab environment. First, we form a matrix of input data and calculate the correlation coefficients using the function "corrcoef" (Table 7).

Next, we use the function regards (responses, DATA, 'model'), which is designed to calculate the parameters of the multiple regression model for the vector of the dependent variable responses values, the matrix of independent variables DATA, regression model 'model'. The function displays a graphical window with a set of statistics that are used to assess the quality of the multiple regression models. To select, it is necessary to note the relevant notes. Selected statistics with specified variable IDs will be calculated and exported to MATALAB (figure 8).
Table 7 Input date to determine the dependence of GDP on the number of enterprises that use information and digital technologies in their activities

\begin{tabular}{|c|c|c|c|}
\hline Year & $\begin{array}{c}\text { The share of } \\
\text { the number } \\
\text { of enterprises } \\
\text { that } \\
\text { implement } \\
\text { information } \\
\text { innovation, } \\
\text { \% (x2) }\end{array}$ & $\begin{array}{c}\text { Information } \\
\text { and } \\
\text { communication } \\
\mathbf{( x 1 )}\end{array}$ & $\begin{array}{c}\text { GDP, mIn. } \\
\text { UAH. (Y) }\end{array}$ \\
\hline 2012 & 13,6 & 66568 & 1404669 \\
\hline 2013 & 13,6 & 86377 & 1465198 \\
\hline 2014 & 12,1 & 114355 & 1586915 \\
\hline 2015 & 15,2 & 116136 & 1988544 \\
\hline 2016 & 16,6 & 129704 & 2385367 \\
\hline 2017 & 14,3 & 146909 & 2983882 \\
\hline 2018 & 15,6 & 174622 & 3560596 \\
\hline 2019 & 13,8 & 206147 & 3974564 \\
\hline
\end{tabular}

Source: formed and calculated by the author 


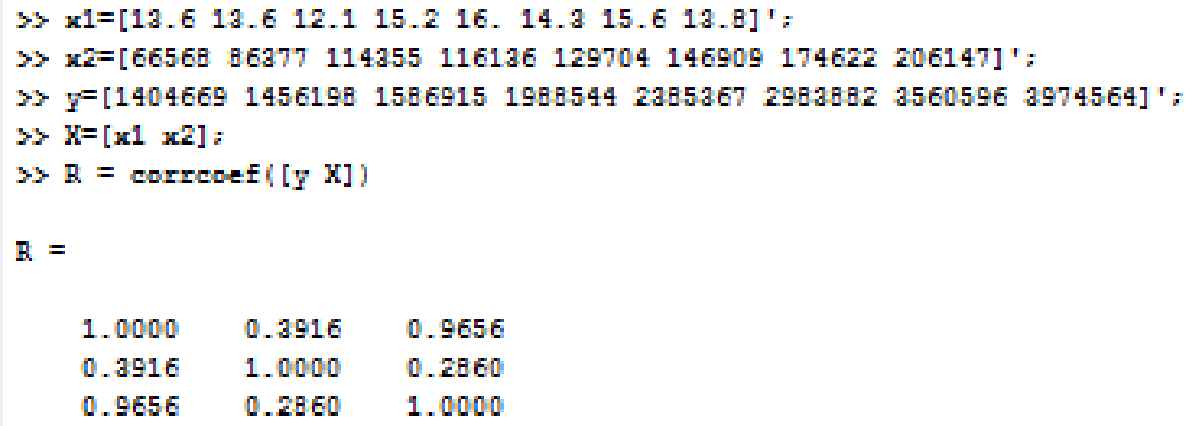

Fig. 8. Input date

Source: calculated by the author

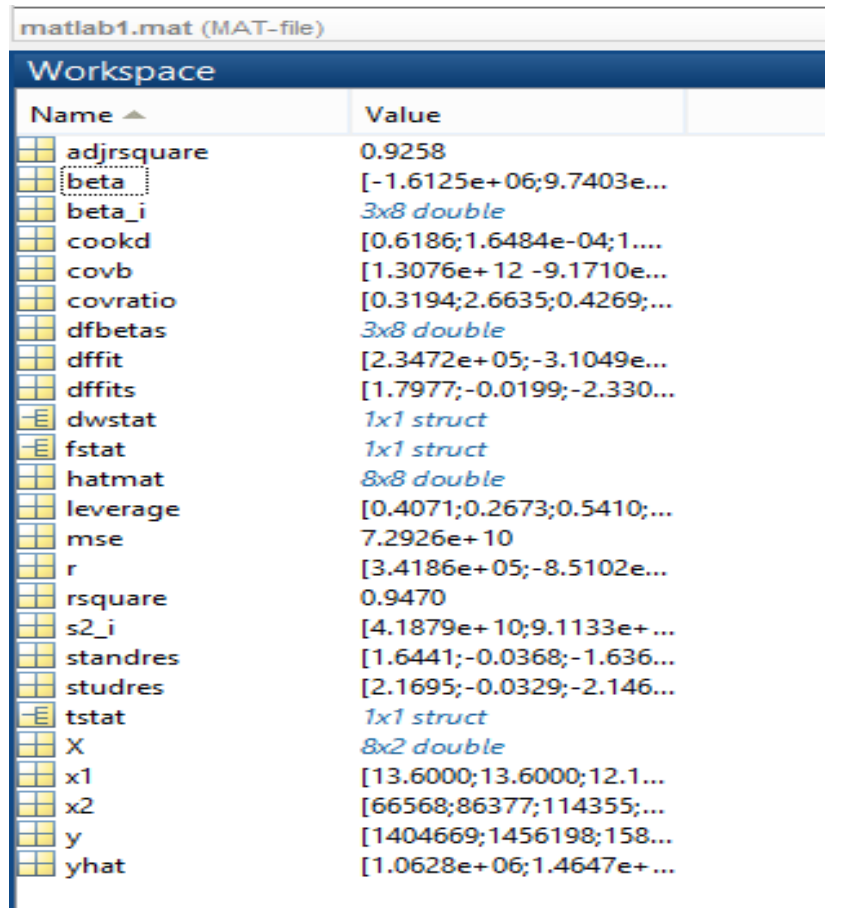

Fig. 9. Statistics with specified variable IDs

Source: formed and calculated by the author

According to the results of statistical processes, the following regression model was obtained:

$$
Y=-1612467,74+20,29 * x_{1}+97403,15 * x_{2}
$$

Based on the characteristics given in Figures 8 and 9 , it can be concluded that the formed model is adequate as the statistical characteristics are within acceptable limits. Thus, if the share of the number of enterprises that innovate increases by $1 \%$, GDP will increase by 20.29 million. UAH under other constant conditions. If the number of enterprises in the information and communication industry increases by
1\%, GDP will increase by UAH 97,403.15 million. However, examining the correlation between dependent and independent variables, it can be concluded that there is not a close relationship between the GDP function and the share of the number of enterprises that innovate, so it is necessary to conduct a stepwise regression using the stepwise function.

The results of the implementation of this function are shown in Figure 10. To do this, we should implement a step-by-step regression algorithm with the exception of variables (stepwise function), given that the equation should include only one of the closely related variables. 


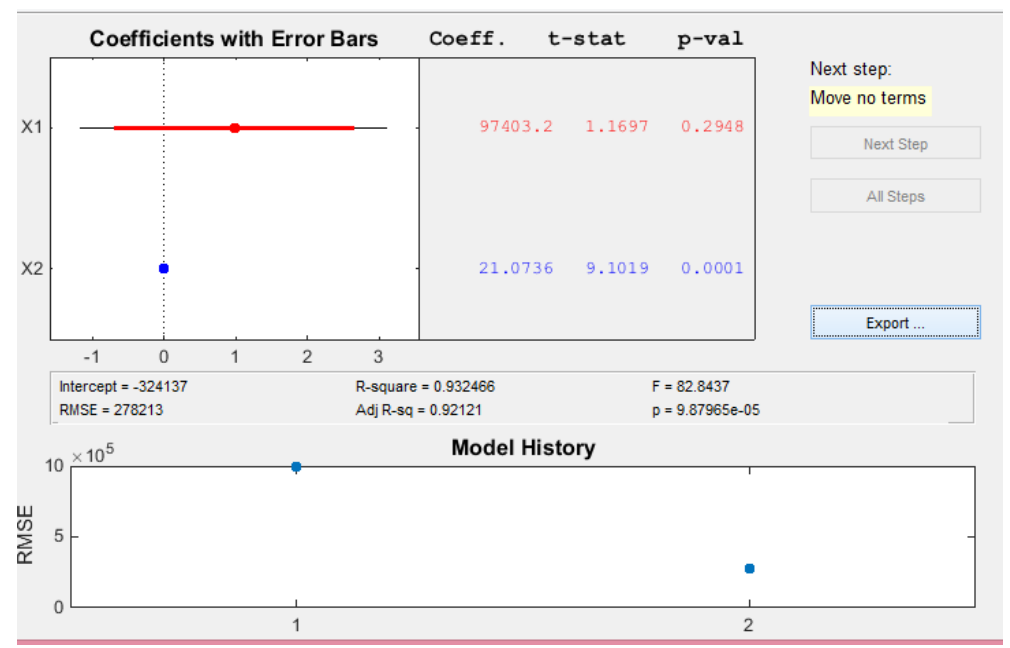

Fig. 10. Coefficients with Error Bar

Source: formed and calculated by the author

According to the results of the statistical processes, the following functional dependence was obtained:

$$
Y=-324137+21.0736 * x_{1}
$$

After the implementation of the step-by-step regression process, it can be concluded that the increase in the number of enterprises in the information and communication sphere by 1 will lead to an increase in GDP by UAH 21.0736 million.

\section{Conclusions and recommendations}

After conducting a study of the development of industries, it was found that during the study period, the total number of businesses is growing, which indicates a revival of economic activity by the end of 2019. The largest growth rate of the business entities number is characterized by the information and communication industry, the growth rate of their number was $11 \%$ at the end of the period. Which indicates the intensification of the information and digital technologies development and, their introduction into the activities of economic entities? Therefore, there is need to assess the level of information and communication technologies usage in domestic enterprises. Research has shown that domestic companies use cloud computing services, big data sources to analyze big data, 3D printing, external links to the Internet, their own websites and ecommerce through the network, Internet, etc. The most intensive use is usually external communication with the Internet, but only $20 \%$ of Ukrainian enterprises had the maximum speed of a fixed broadband connection (from Mbps and more) to the Internet. This problem indicates the need to increase the speed of a fixed broadband connection (from $100 \mathrm{Mbps}$ and more) to the internet. Regarding websites, only $35 \%$ of domestic enterprises had their own websites; the main areas provided by the company's own websites were customer service and the implementation of electronic links to company profiles on social media. This situation indicates rather undeveloped directions of this information communication technology, so it is necessary to expand the functionality of websites developed in enterprises. However, e-commerce is developing quite intensively, however, only $20 \%$ of the total number of enterprises purchased goods or services via the Internet and only $5 \%$ of domestic enterprises received orders via the Internet to sell goods or services. Therefore, e-commerce should be intensified. The positive point is the use of "big data" sources for the analysis of "big data" in the activities of domestic enterprises. However, in the realities of domestic enterprises, only 5-6\% of enterprises analyze the "big data". Regarding cloud computing, only $10 \%$ of enterprises purchase cloud computing services, which accordingly indicates the need to develop this area of information and communication technologies.

Studies of the relationship between GDP and the number of enterprises in the information and communication industry have shown that there is a close relationship between the resulting and factorial feature, and the above equation (2) is adequate and can be used for forecasting.

\section{References}

1. B-S. Aferdita, B-N. Mihane. Information Technology and the Digital Economy. Med. J. of Soc. Scien. (2015). doi: 6. 10.5901/mjss.2015.v6n6p78

2. Th. Papadopoulos, K. N. Baltas, M. E. Balta The use of digital technologies by small and medium enterprises during COVID-19: Implications for theory and practice. Int. J. of Inf. Man. 55, (2020) doi:10.1016/j.ijinfomgt.2020.102192.

3. U. Andrea, Ch. Davide, Ch. Vittorio, F. Federico, The role of digital technologies in the innovation process, in Proceedings of the 24th Innovation and 
Product Development Management Conference, IPDMC, June 2017, Reykjavik, Iceland (2017)

4. M. L. Zapata, L. Berrah, L. Tabourot, Is a digital transformation framework enough for manufacturing smart products? The case of Small and Medium Enterprises, Proc. Manufact. 42, 7075, (2020), doi:10.1016/j.promfg.2020.02.024

5. R. Eller, Ph. Alford, A. Kallmünzer, M. Peters, Antecedents, consequences, and challenges of small and medium-sized enterprise digitalization. J. of Bus. Res. 112, 119-127, (2020), doi:10.1016/j.jbusres.2020.03.004

6. A. A. Shaikh, R. Sharma, H. Karjaluoto, Digital innovation \& enterprise in the sharing economy: An action research agenda, Dig. Bus. (2021). doi:10.1016/j.digbus.2021.100002

7. L. Horal, S. Korol, M. Havrylenko, I. Khvostina, V. Shyiko. (2020). The Management of BusinessProcesses Strategic Sectors of Economy on Digital Transformation Conditions, in Proceedings of the III International Scientific Congress Society of Ambient Intelligence ISC-SAI 2020, March 2020, Ukra.ine (2020)

8. V. Soloviev, S. Semerikov, V. Solovieva (2020). Lempel-Ziv Complexity and Crises of Cryptocurrency Market, in Proceedings of the III International Scientific Congress Society of Ambient Intelligence ISC-SAI 2020, March 2020, Ukraine (2020)

9. A. D. Olofsson, G. Fransson, J. O. Lindberg, A study of the use of digital technology and its conditions with a view to understanding what вЂ回adequate digital competenceв $\mathrm{C}^{\mathrm{TM}}$ may mean in a national policy initiative. Educ. Stud. 46, 727 $-743,(2020)$. doi:10.1080/03055698.2019.1651694

10. V.S. Litvinenko, Digital Economy as a Factor in the Technological Development of the Mineral Sector. Nat Resour Res 29, 1521-1541 (2020). doi: 10.1007/s11053-019-09568-4

11. Hu, N., Tian, Z., Lu, H. et al. A multiple-kernel clustering based intrusion detection scheme for $5 \mathrm{G}$ and IoT networks. Int. J. Mach. Learn. \& Cyber. (2021). doi:10.1007/s13042-020-01253-w

12. G. Mamonova, N. Maidaniuk Mathematical Tools for the Internet of Things Analysis. Cybern Syst Anal 56, 621-627 (2020). doi:org/10.1007/s10559-020-00279-w

13. B. He, KJ. Bai Digital twin-based sustainable intelligent manufacturing: a review. Adv. Manuf. 9, 1-21 (2021). doi:10.1007/s40436-020-00302-5

14. M. Anshari, M.A. Arine, N. Nurhidayah. et al. Factors influencing individual in adopting eWallet. J Financ Serv Mark 26, 10-23 (2021). doi:10.1057/s41264-020-00079-5

15. http://www.ukrstat.gov.ua 